\title{
Investigation of repeated economiser tube failures of a 135 tph cold cyclone CFB boiler - a case study
}

There were quick and successive failures of economiser tubes in a four years old cold cyclone circulating fluidised bed 135 tph boiler in a short span of three months. Advance inspection and failure analysis, change in operational practices were used to get the boiler running at full load at the earliest possible time. This paper presents details of the process of inspection, maintenance, operation and failure investigation carried out for the economiser tubes of the boiler. The failure of the economiser tubes was due to external corrosion of the tubes furnace fire side due to presence of sulphur in coal, accompanied by localised erosion by high levels of alpha-quartz in coal ash.

Keywords: Economiser, tube failure, cyclone, CFB boiler, mechanism.

\subsection{Introduction}

$\mathrm{B}$ oiler tubes are subject to a wide variety of failures involving one or several mechanisms. Forced outage of a boiler caused by various reasons but, about 50 to $60 \%$ of the total outage can be attributed to tube failure. The main component of a modern water tube boiler consists of tubes and pipes of various specifications and orientations to suit the design requirements contingent upon the flow and heat transfer characteristics backed by well improved latest design and construction, automatic control and any safety systems, is still prone to generation loss due to tube failures.

Most prominent mechanisms those lead to boiler tube and other pressure parts failures are corrosion including pitting and erosion, mechanical environmental processes including stress-corrosion cracking and hydrogen damage, fracture including fatigue fracture, thermal fatigue and stress-rupture and distortion involving thermal - expansion effects or creep. The root causes of failure can generally be classified as: (a) Design defects; (b) Defects caused by weakening of the structures; (c) Improper operation; (d) Poor maintenance and inadequate water treatment and (e) Miscellaneous causes. Most of the failures of a steam generating plant occurs in the pressurised components, that is, the tubing, piping and

Dr. Chittatosh Bhattacharya, Ph.D, FIE(I); ChE(I), Dy. Director, National Power Training Institute (Eastern Region). Email: chittatoshbhattacharya@asme.org pressure vessels that constitute the steam generating portion of the system. Weakening of the structure can be divided into three somewhat overlapping categories: (1) Weakening of pressure parts; (2) Failure of supports; (3) Mechanical damage. The various conditions that may cause weakening of boiler pressure parts viz. overheating, loss of metal due to corrosion, weakening of the furnace wall because of improper combustion or flame impingement and soot blower erosion can be considered in the context of tube failures.

\subsection{Brief description of boiler system}

\subsection{Cold Cyclone CFBC}

Boiler offers valuable solution to reduce pollution. Salient advantages are: (a) Fuel of different types/origin and quality can be burnt at high efficiency. (b) Sulphur dioxide, hydrogen chloride, hydrogen fluoride released during combustion is retained in the ash with the help of limestone. (c) Due to low combustion temperature and combustion in stages, there is only a little development of $\mathrm{NO}_{\mathrm{x}}$. Flue gas cleaning systems are not necessary and thus eliminate additional efficiency losses. Lower $\mathrm{NO}_{\mathrm{x}}$ formation helped by staged firing cold cyclone.

\subsection{WATER AND STEAM CIRCUIT}

Feed water is supplied to economizer-I via feed control station. Economizer-I is located in upper portion of second pass and interconnecting piping takes feed water to inlet header of economizer-II in upper portion of combustor. Drum receives feed water from economizer-II. Drum is connected to bottom headers of combustor via down comers and supply pipes for feeding water. The furnace walls headers located in upper portion of combustor convey mixture of steam and water to drum through riser tubes. As the water in furnace walls rises, its place is taken by denser/colder water from down comer through natural circulation and continues. As the water-steam mixture flowing upwards through furnace tubes, top water wall headers and risers enters the drum, separation of steam from water takes place. Steam from drum flows to saturated steam header located slightly above the steam drum. Steam then flows through superheater-I, superheater-II and superheater-III absorbing the heat from outgoing flue gases of combustor. In economiser-I, flue gases 
from cyclones flow downwards towards air heater whereas the feed water moves upwards. The economiser coils are suspended from steel structure. Economiser-I is counter-flow type heat exchanger and of plain tube configuration. The flue gases flow upwards through gaps between economiser II coils. The water also moves upwards to economiser outlet header. Feed water flows from economiser-II outlet header to drum through nozzles with thermal sleeves. Inside the steam drum, perforated feed pipes ensure even distribution of feed water. Economiser-II is parallel-flow type heat exchanger and of plain tube configuration. ducts of both PA fans are joined together to form a single duct entering air preheater. Primary air (PA) and secondary/ tertiary air (SA/TA) flows through the tubular air preheater in 2 stages. This splits up into combustion air and dilution air. The primary air is blown into the fluidised bed via PA nozzles. Generally, primary air is routed through combustion air, and dilution air during cold start up. Secondary air is further split into secondary and tertiary air ducts with isolation/control dampers after air preheater. The secondary air is injected into the boiler by means of nozzles located above the fluidised bed. The tertiary air is supplied to the boiler through nozzles, located above the secondary air nozzles.

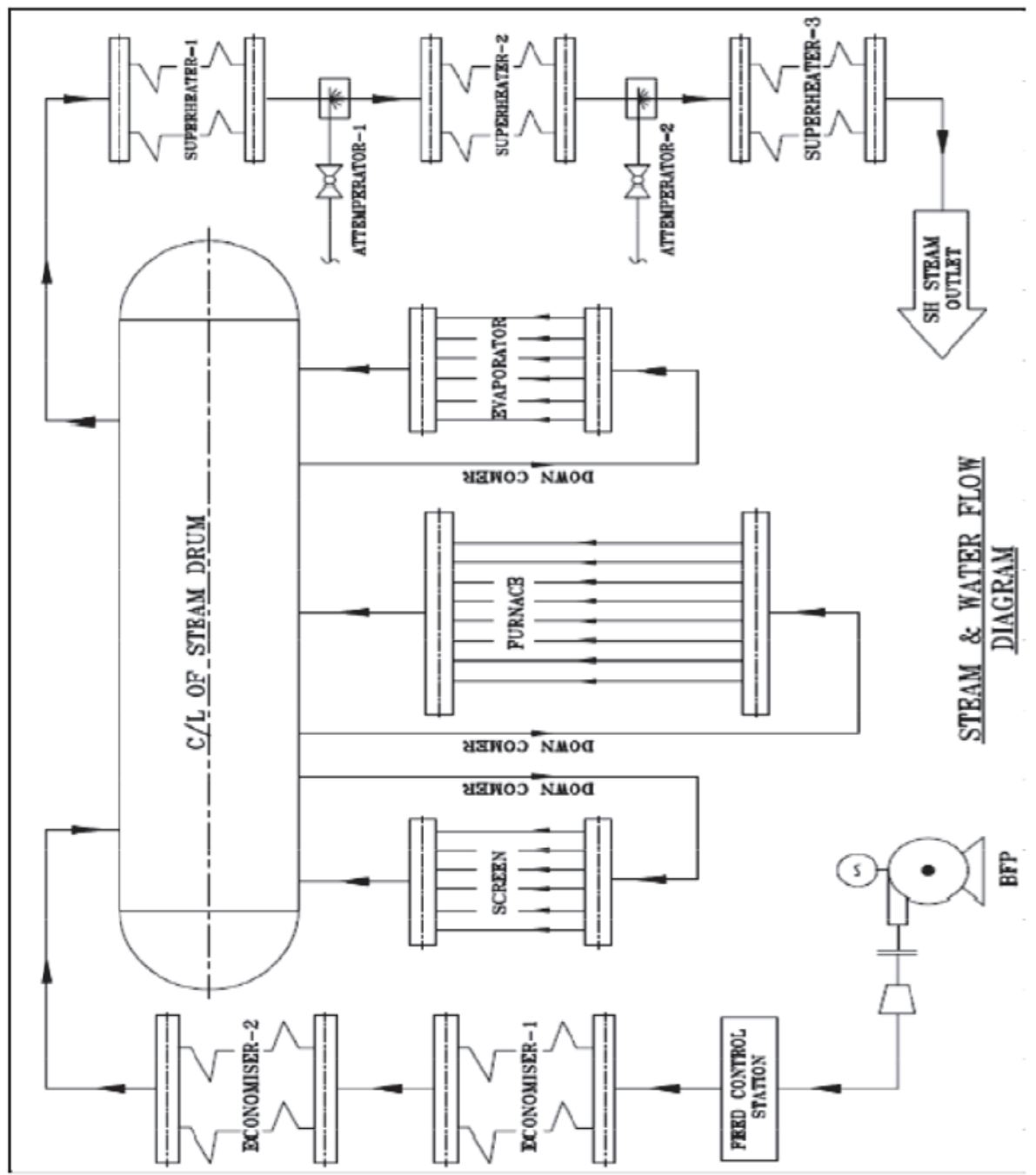

Fig.1: Schematic diagram of water and steam circuit

\subsection{Flue GAS PATH}

The flue gas-side pressure in the free board, above the fluidised bed is around (-) 30 to (-) $50 \mathrm{~mm}$ WC. From here, the fly ash charged flue gases from combustion are conveyed to induced-draught fan. In the first pass of boiler, flue gas passes over screen, the final-stage i.e. superheater-3, superheater-2, superheater-1, evaporator and econimizer-2 reaching the second boiler pass via cyclone separators. The cyclone separator recirculates the ash discharged from the fluidised bed a number of times. Approximately $95-97 \%$ of the ash contained in the flue gases is being separated in the cyclones.

\subsection{CyClones}

The cyclones are of a selfsupporting plate constructional design complete with wear protection. Ash laden flue gas enters from combustor exit into cyclones. The raw gas passes via the raw gas duct into the raw gas spiral. At this entry, the flue gas is centrifugally deflected. Due to the centrifugal forces the ash particles are flung out from the gas flow towards shell of cyclone. They overcome the flow resistance, which is caused by the sinking flow to the immersion pipe inlet. At the cyclone shell, the ash moves downwards into the stand pipes and finally in the siphon. The clean gases leave the cyclone via a centrally arranged immersion pipe. There are two cyclones in the boiler placed in front side. Ash collected in cyclones are re-circulated back into the furnace via siphon. There are two siphons in the boiler in the front side of boiler. In the second pass of boiler, the flue gases pass through economizer-1 and 


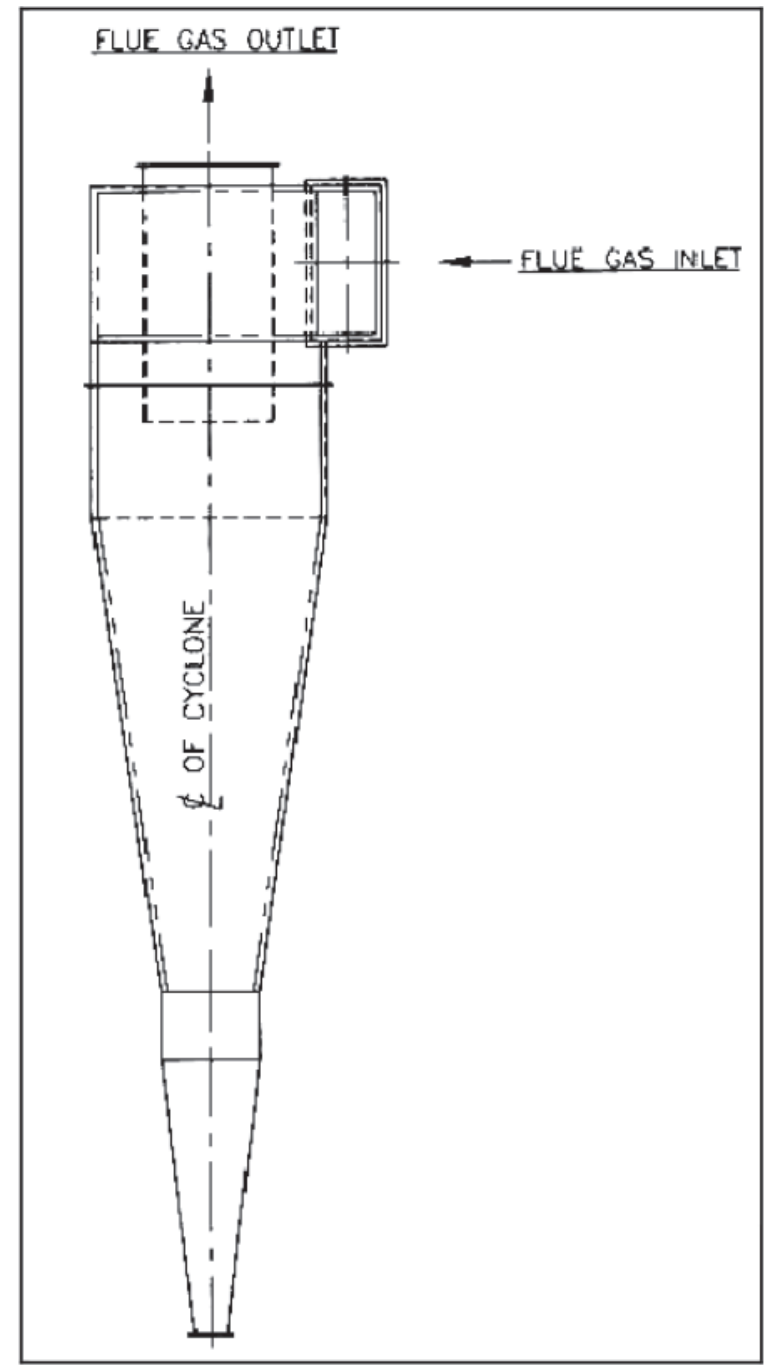

Fig.2: Sketch of cyclone

then the tubular air preheater. The primary air and secondary/ tertiary air are heated here.

\subsection{Brief description of failure}

The boiler had tripped on low drum level caused due to water leakage from the economiser tube. On opening the boiler cyclone side economiser manhole, the chamber was found with water. Economiser tube facing the fire side of the chamber was found leaking. Two of the tubes were found ruptured opened up and two tubes were found with pinhole leak. Though damaged tubes were found with sticking ash, any significant bulging of tubes was not observed. The following figures and tables contain the analysis conducted on the two failed service-exposed economiser tubes. The primary objective is to find out the reason for failure of the citedtubes.

\section{Tube components studied}

(a) Sample-1 : Failed service exposed economiser tube '1' (43 MW unit CFBC unit 135 tph)
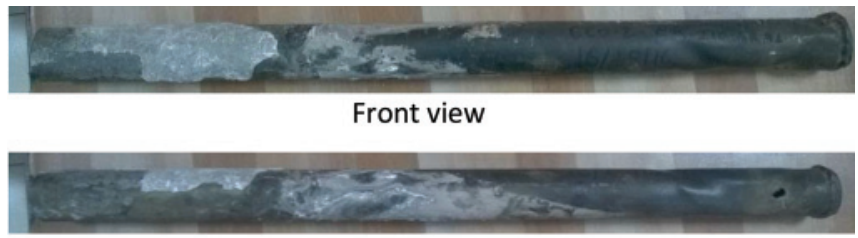

Top view

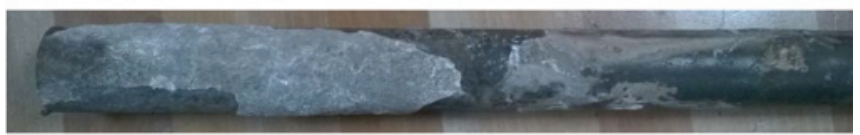

Corrosive part

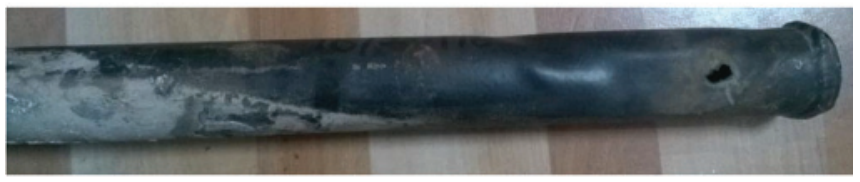

Damage part

Fig.3: Failed economiser tube 1

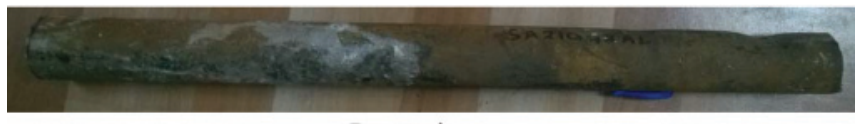

Front view

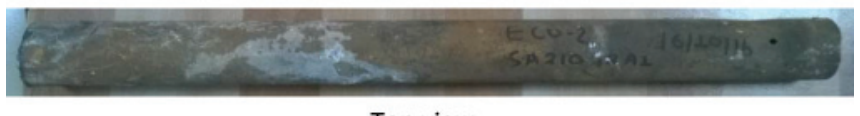

Top view

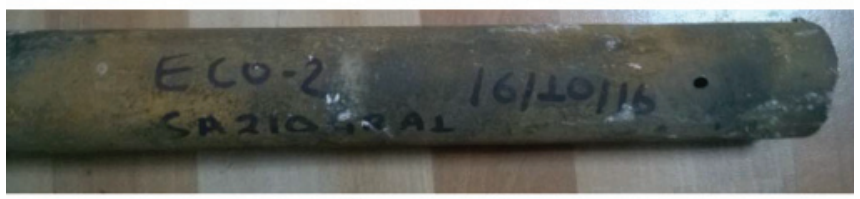

Damage part

Fig.4: Failed economiser tube 2

(b) Sample-2 : Failed service exposed economiser tube '2' (43 MW unit CFBC unit 135 tph)

Procedure: For failure analysis and health assessment study: (a) Visual inspection; (b) Dimensional measurement; (c) Chemical analysis (supplied by client organisation); (d) Any other parametric analysis necessary during the course of investigation was done.

Technical information provided: (i) For economiser 2 Tubes: (a) Material specification of tubes: SA 210 A1; (b) Nominal dimensions: $\mathrm{OD}=38.1 \mathrm{~mm}$ thickness $=4.0 \mathrm{~mm}$; (c) Working temperature: Tube $450^{\circ} \mathrm{C}+30^{\circ} \mathrm{C}$; (d) Working pressure: $96.7+0.5 \mathrm{~kg} / \mathrm{cm}^{2}$

Visual inspection of leaking economiser tubes: Dimensional Measurement: Wall thickness assessments through outer diameter (OD) measurements using vernier caliper were carried out on the two tubes. The results are self-explanatory and shown in Tables 2 and 3 . 
Table 1: Avg. proximate analysis (CFBC)

\begin{tabular}{cccccc}
\hline & & & & \multicolumn{2}{c}{ Avg. Sieve analysis of mixed fuel CFBC) } \\
\cline { 5 - 6 } Particulars & Coal & Char & Feed Fuel & $+7 \mathrm{~mm}(\%)$ & 2.02 \\
SM \% & 6.00 & 7.91 & 6.98 & $+6 \mathrm{~mm}(\%)$ & 2.50 \\
IM \% & 2.04 & 1.07 & 1.55 & $+5 \mathrm{~mm}(\%)$ & 4.04 \\
ASH \% & 46.84 & 70.31 & 58.44 & $+4 \mathrm{~mm}(\%)$ & 7.28 \\
VM \% & 22.46 & 6.28 & 14.53 & $+3 \mathrm{~mm}(\%)$ & 14.63 \\
FC\% & 28.66 & 22.34 & 25.48 & $+2 \mathrm{~mm}(\%)$ & 19.92 \\
GCV(K.CAL/KG) & 3521 & 1640 & 2631 & $-1 \mathrm{~mm}(\%)$ & 48.61 \\
\hline
\end{tabular}

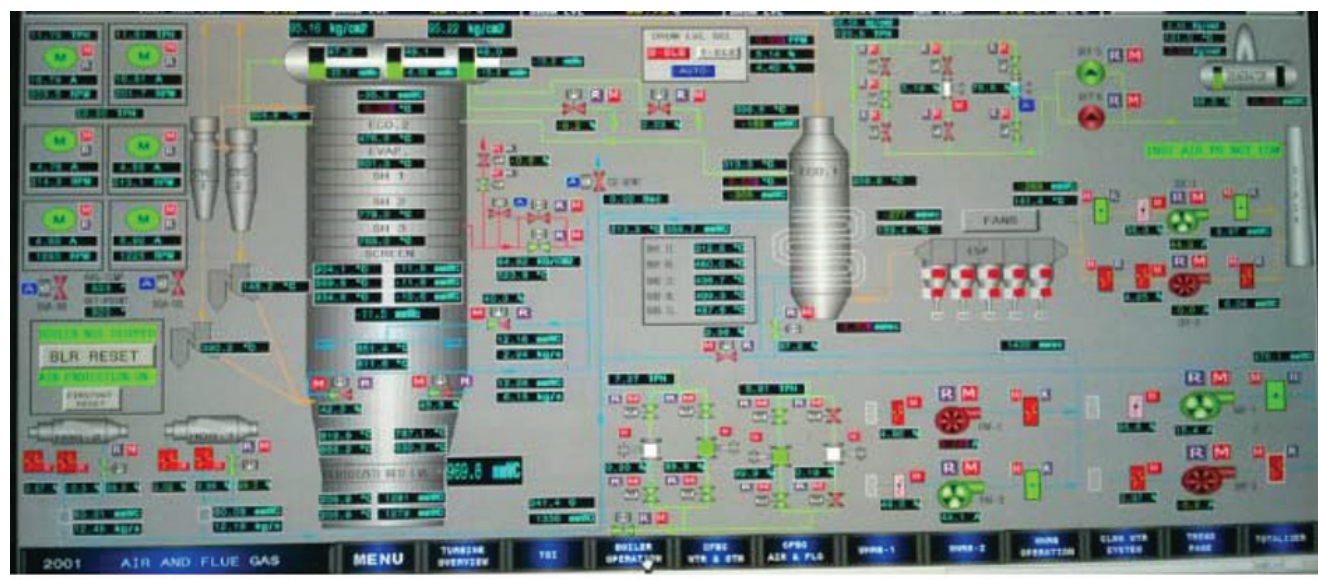

Fig.5: Air and

flue gas

passage 1

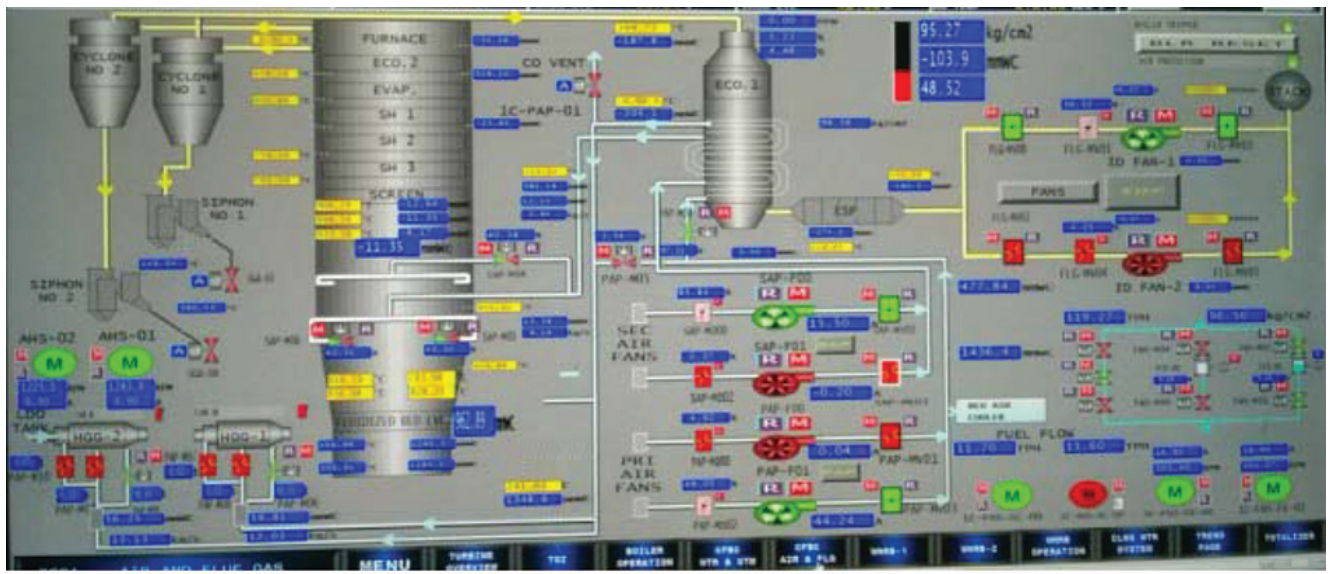

Fig.6: Air and

flue gas

passage 2

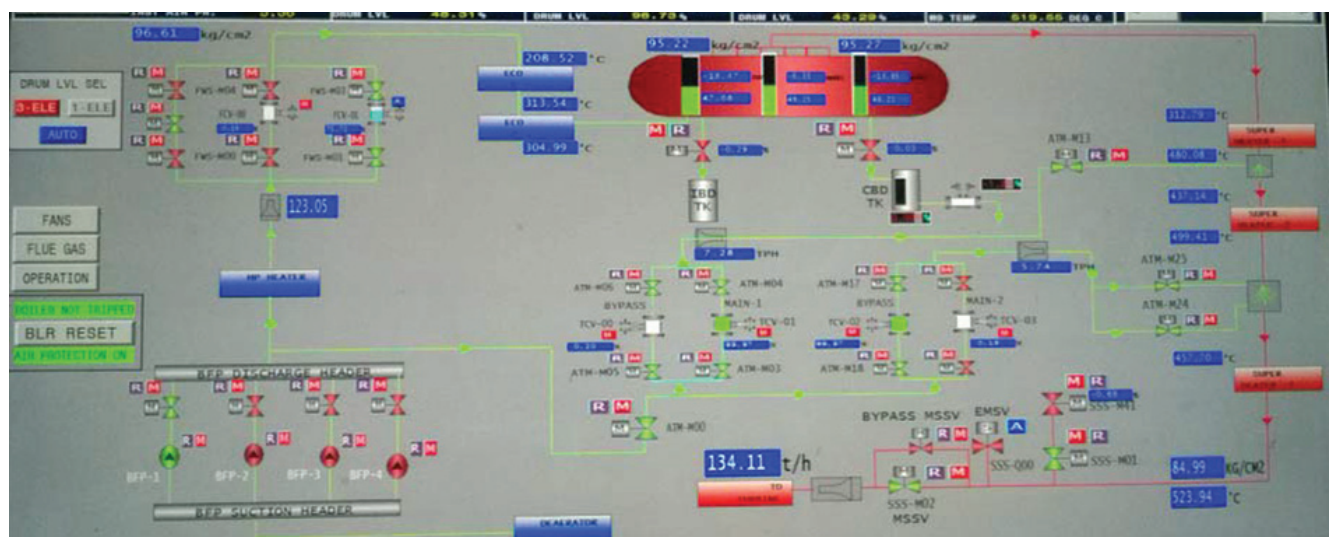

Fig.7: Water and steam circuit 


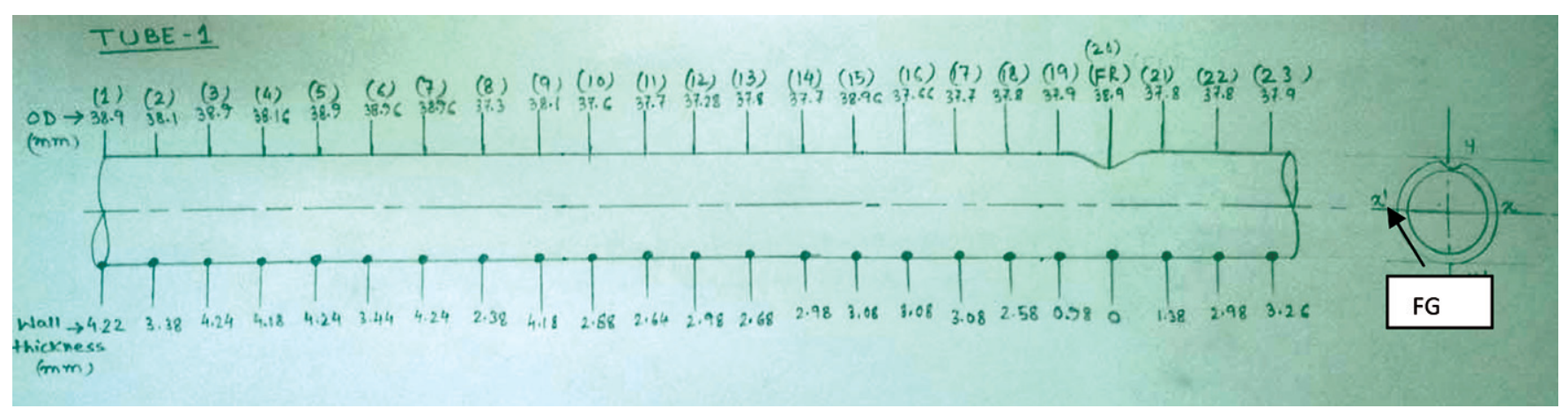

Fig.8: Measured readings of failed economiser tube 1

$(\mathrm{FR})$ - Failure region; OD - Outer diameter $\rightarrow$ Wall thickness flue gas direction

OD corresponding to points $1,2,3, \ldots \mathrm{FR}, \ldots, 23$ in $\mathrm{XX}^{\prime}$ and $\mathrm{YY}^{\prime}$ directions.

TABLe 2

\begin{tabular}{|c|c|c|c|c|}
\hline • & $\begin{array}{c}\text { Distance from right } \\
\text { (in } \mathrm{mm} \text { ) }\end{array}$ & $\begin{array}{l}\text { Along } \mathrm{XX}^{1} \\
\text { (in } \mathrm{mm} \text { ) }\end{array}$ & $\begin{array}{l}\text { Along YY } \\
\text { (in } \mathrm{mm} \text { ) }\end{array}$ & $\begin{array}{l}\text { Thickness } \\
\text { (in } \mathrm{mm} \text { ) }\end{array}$ \\
\hline 1 & 230 & 38.9 & 38.94 & 4.22 \\
\hline 2 & 220 & 38.1 & 38.1 & 3.38 \\
\hline 3 & 210 & 38.9 & 38.96 & 4.24 \\
\hline 4 & 200 & 38.16 & 38.9 & 4.18 \\
\hline 5 & 190 & 38.9 & 38.96 & 4.24 \\
\hline 6 & 180 & 38.96 & 38.16 & 3.44 \\
\hline 7 & 170 & 38.96 & 38.96 & 4.24 \\
\hline 8 & 160 & 37.3 & 37.1 & 2.38 \\
\hline 9 & 150 & 38.1 & 38.9 & 4.18 \\
\hline 10 & 140 & 37.6 & 37.6 & 2.88 \\
\hline 11 & 130 & 37.7 & 37.36 & 2.64 \\
\hline 12 & 120 & 37.28 & 37.7 & 2.98 \\
\hline 13 & 110 & 37.8 & 37.4 & 2.68 \\
\hline 14 & 100 & 37.7 & 37.7 & 2.98 \\
\hline 15 & 90 & 38.96 & 37.8 & 3.08 \\
\hline 16 & 80 & 37.66 & 37.8 & 3.08 \\
\hline 17 & 70 & 37.7 & 37.8 & 3.08 \\
\hline 18 & 60 & 37.8 & 37.3 & 2.58 \\
\hline 19 & 50 & 37.9 & 35.7 & 0.98 \\
\hline $20(\mathrm{FR})$ & 40 & 38.9 & 34.72 & 0 \\
\hline 21 & 30 & 37.8 & 36.1 & 1.38 \\
\hline 22 & 20 & 37.8 & 37.7 & 2.98 \\
\hline 23 & 10 & 37.9 & 37.98 & 3.26 \\
\hline
\end{tabular}

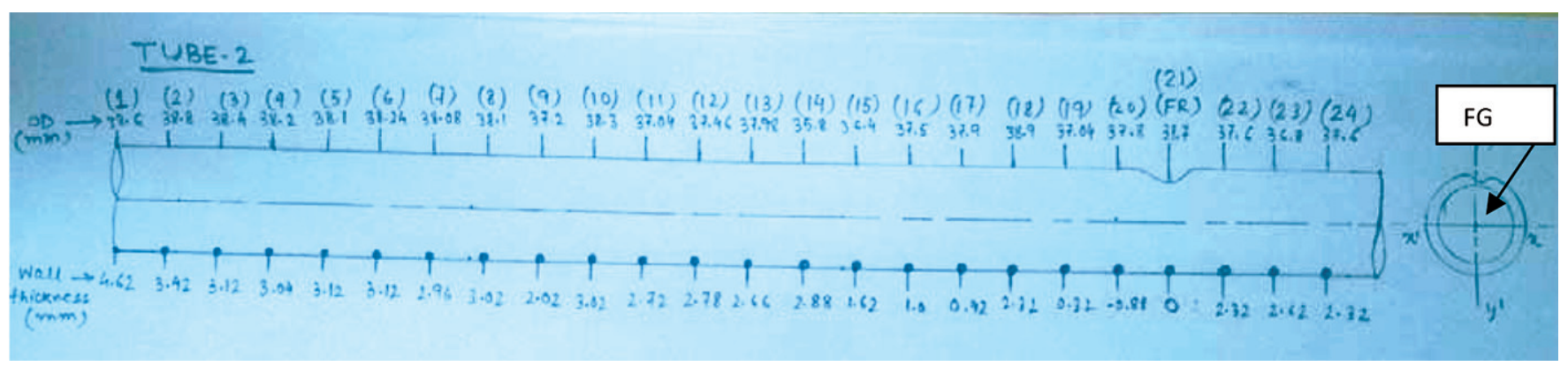

Fig.9: Measured readings of failed economiser tube 2

(FR) - Failure Region; OD - Outer diameter $\rightarrow$ Wall thickness flue gas direction

OD corresponding to points $1,2,3, \ldots, \mathrm{FR}, \ldots, 24$ in $\mathrm{XX}^{\prime}$ and $\mathrm{YY}^{\prime}$ directions 
TABLe 3

\begin{tabular}{|c|c|c|c|c|}
\hline & $\begin{array}{c}\text { Distance from right } \\
\text { (in mm) }\end{array}$ & $\begin{array}{l}\text { Along XX }{ }^{1} \\
\text { (in } \mathrm{mm} \text { ) }\end{array}$ & $\begin{array}{l}\text { Along YY } Y^{1} \\
\text { (in } \mathrm{mm} \text { ) }\end{array}$ & $\begin{array}{l}\text { Thickness } \\
\text { (in mm) }\end{array}$ \\
\hline 1 & 250 & 38.6 & 39.7 & 4.62 \\
\hline 2 & 240 & 38.8 & 38.5 & 3.42 \\
\hline 3 & 230 & 38.4 & 38.2 & 3.12 \\
\hline 4 & 220 & 38.2 & 38.14 & 3.04 \\
\hline 5 & 210 & 38.1 & 38.2 & 3.12 \\
\hline 6 & 200 & 38.24 & 38.2 & 3.12 \\
\hline 7 & 190 & 38.08 & 38.04 & 2.96 \\
\hline 8 & 180 & 38.1 & 38.1 & 3.02 \\
\hline 9 & 170 & 37.2 & 37.1 & 2.02 \\
\hline 10 & 160 & 38.3 & 38.1 & 3.02 \\
\hline 11 & 150 & 37.04 & 37.8 & 2.72 \\
\hline 12 & 140 & 37.46 & 37.86 & 2.78 \\
\hline 13 & 130 & 37.98 & 37.74 & 2.66 \\
\hline 14 & 120 & 35.8 & 37.96 & 2.88 \\
\hline 15 & 110 & 36.4 & 36.7 & 1.62 \\
\hline 16 & 100 & 37.5 & 36.08 & 1 \\
\hline 17 & 90 & 37.9 & 35.5 & 0.42 \\
\hline 18 & 80 & 38.9 & 37.4 & 2.32 \\
\hline 19 & 70 & 37.04 & 35.4 & 0.32 \\
\hline 20 & 60 & 37.8 & 34.2 & -0.88 \\
\hline $21(F R)$ & 50 & 37.7 & 35.3 & 0 \\
\hline 22 & 40 & 37.6 & 37.4 & 2.32 \\
\hline 23 & 30 & 36.8 & 37.7 & 2.62 \\
\hline 24 & 20 & 37.6 & 37.4 & 2.32 \\
\hline
\end{tabular}

TABLE 4: COLLECTED PHYSICAL DATA FROM PLANT - TEMPERATURE AND PRESSURE READINGS

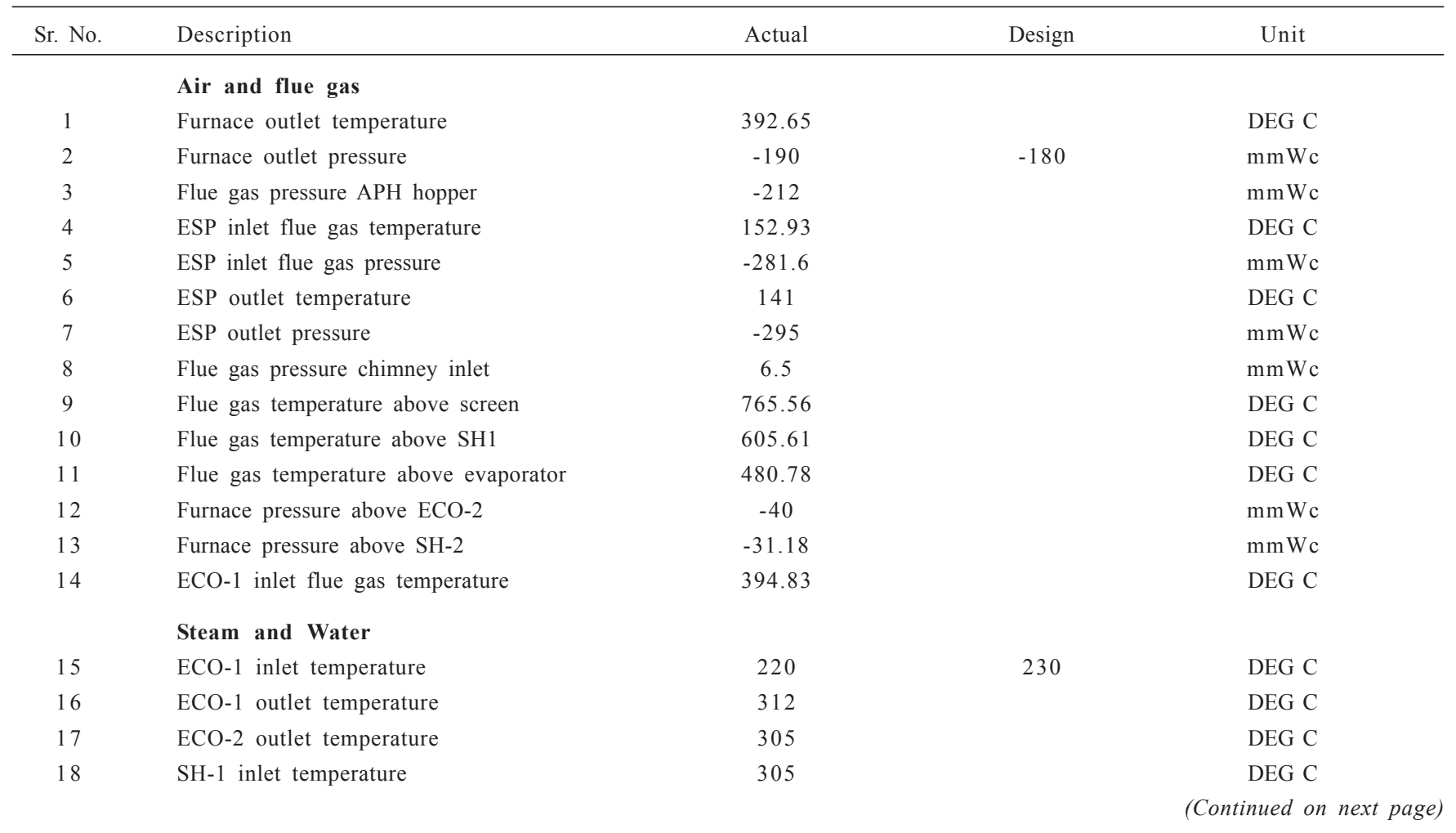




\begin{tabular}{|c|c|c|c|c|}
\hline Sr. No. & Description & Actual & Design & Unit \\
\hline 19 & SH-1 outlet temperature & 475 & $400-450$ & DEG C \\
\hline 20 & $\mathrm{SH}-2$ inlet temperature & 435 & 440 & DEG C \\
\hline 21 & $\mathrm{SH}-2$ outlet temperature & 500 & & DEG C \\
\hline 22 & $\mathrm{SH}-3$ inlet temperature & 460 & $450-510$ & DEG C \\
\hline 23 & SH-3 outlet temperature & 525 & 540 & DEG C \\
\hline \multirow[t]{2}{*}{24} & Drum pressure & 96 & 105 & $\mathrm{Kg} / \mathrm{cm}^{2}$ \\
\hline & Bed temperature & & & \\
\hline 25 & Average & 850 & $850-860$ & DEG C \\
\hline 26 & Furnace temperature & 850 & & DEG C \\
\hline 27 & Furnace temperature & 816 & & DEG C \\
\hline 28 & Furnace temperature below screen & 908 & & DEG C \\
\hline 29 & Furnace temperature below screen & 891 & & DEG C \\
\hline 30 & Furnace temperature below screen & 937 & & DEG C \\
\hline 31 & PA discharge pressure & 1417 & 1600 & $\mathrm{mmWc}$ \\
\hline 32 & PA pressure to hot gas generation & 1313 & & $\mathrm{mmWc}$ \\
\hline 33 & Wind box temperature & 210 & & DEG C \\
\hline 34 & Bed height & 950 & $500-1400$ & $\mathrm{Mm}$ \\
\hline 35 & PA air flow & 24 & 15 & $\mathrm{Kg} / \mathrm{s}$ \\
\hline 36 & SA discharge pressure & 477 & $400-600$ & $\mathrm{mmWc}$ \\
\hline 37 & SA pressure to furnace & 360 & & $\mathrm{mmWc}$ \\
\hline 38 & SA flow & 6 & 7 & $\mathrm{Kg} / \mathrm{s}$ \\
\hline \multirow[t]{2}{*}{39} & TA flow & 3 & 2.5 & $\mathrm{Kg} / \mathrm{s}$ \\
\hline & Drag chain feeder & & & \\
\hline 40 & Speed & 200 & & RPM \\
\hline 41 & Char feeder & 220 & & RPM \\
\hline 42 & $\mathrm{O}_{2}$ & 4.4 & & $\%$ \\
\hline 43 & $\mathrm{O}_{2}$ & 5.2 & & $\%$ \\
\hline 44 & Steam flow & 135 & & ТPH (tonne/hr) \\
\hline
\end{tabular}

\subsection{Chemical analysis of corrosion deposits}

Chemical analysis of the corrosion product inside failed tubes was carried out at different laboratories. The results of the chemical analysis of deposits is given in Table 5. Sample Description: Boiler tube scaling sample identification

\subsection{Chemical analysis of tUbe materials}

Metal samples from the two tubes were chemically analysed to estimate the weight percentage of the constituent elements.
TABle 5: Test Specification: BoILeR tUbe SCALING: Test method: IS13624/1993 (REAFFIRMED 2003)

\begin{tabular}{clcc}
\hline & Parameters (elements) & Unit & Result \\
\hline 1 & Calcium $(\mathrm{Ca})$ & $\%$ & 9.39 \\
2 & Magnesium $(\mathrm{Mg})$ & $\%$ & 4.55 \\
3 & Sodium $(\mathrm{Na})$ & $\%$ & 0.30 \\
4 & Potassium $(\mathrm{K})$ & $\%$ & 0.18 \\
5 & Sulphur $\left({\left.\mathrm{S} \mathrm{as} \mathrm{SO}_{3}\right)}\right)$ & $\%$ & 22.47 \\
6 & Silica $\left(\mathrm{SiO}_{2}\right)$ & $\%$ & 20.81 \\
7 & Bicarbonate & $\%$ & NIL \\
\hline
\end{tabular}

TABLE 6: ECONOMISER TUBES METAL COMPOSITION

\begin{tabular}{|c|c|c|c|c|}
\hline \multirow[t]{2}{*}{$\begin{array}{l}\text { Sample } \\
\text { No. }\end{array}$} & \multirow[t]{2}{*}{$\begin{array}{l}\text { Tube } \\
\text { Identification }\end{array}$} & \multicolumn{3}{|c|}{$\begin{array}{l}\text { Composition } \\
\text { (weight per cent) }\end{array}$} \\
\hline & & $\mathrm{C}$ & $\mathrm{Si}$ & $\mathrm{Mn}$ \\
\hline 1 and 2 & Economiser tube & $0.20-0.19$ & $0.15-0.16$ & $0.48-0.49$ \\
\hline $\begin{array}{l}\text { Recommended grade: } \\
\text { SA } 210 \text { A1 }\end{array}$ & $0.27 \max$ & $0.10 \mathrm{~min}$ & $0.93 \max$ & \\
\hline
\end{tabular}




\subsection{Conclusions}

The economiser tube failure prevention mechanism was established with following corrective actions:

(i) Arrangement to measure furnace flue gas outlet temperature: During inspection it was observed that, there was no provision to measure furnace exit gas temperature. There may be more secondary combustion in furnace top due to deviation in loadbased tuning of secondary and tertiary air. The reduced heat transfer rate with rated heat transfer surface in economiser II tubing zone is causing excess flue gas temperature at economiser I inlet. Slag deposit on the outer surface of the tube, possibly due to faulty furnace exit draft set up or unavailable FEG temperature indication for standard operational practice, caused localized increase in metal stress leading to failure while erosion was caused by high velocity ash particles before entry to cyclone. The more fines in the freeboard zone with high velocity high ash coal particles are prime reason of erosion. Corrective measure: Tuning of secondary and tertiary air supply based on metal temperature and flue gas velocity mapping at furnace exit/cyclone entry may help in avoiding re-occurrence of similar failure in future. Long retractable soot-blowers may help in preventing fly ash deposits in economiser II tubes which are not installed now.

(ii) Arrangement to tube surface cleaning: The design/ performance and operational parameters of the economiser tubing at economiser I and economiser II indicated exposure to a temperature slightly above the designed temperature and this may cause in future of graphitization. Graphitisation is considered to be a serious type of microstructural degradation. Therefore, failed tube sample may be given for microstructural analysis to ensure trouble free operation in future. Corrective measure: Proper cleaning must be done to prevent the blockage of the tubes by depositing foreign materials. Moreover, flue gas temperature must be properly controlled to prevent localized increase in flue gas temperature. The sulphur content of the fuel fused slag accumulated at outer surface of failed tubes at the furnace top indicates inadequate combustion and inadequate proportion of sorbent recharge. As such, below $1 \mathrm{~mm}$ coal particle size need to be controlled as per OEM recommendation. The sulphur content in slag may propagate tube external surface damage mechanism that may also tested to verify operational excursion that may be caused by acidic corrosion as a result of leaked steam at initial stage. Since free silica $\left(\mathrm{SiO}_{2}\right)$ concentration is significantly high with average ash content ranging to $65-70 \%$ of the
Dolochar mix, the tube erosion potential is dependent on $\alpha$-quartz concentration and its particle size distribution which may be tested too to determine service life of tubes.

(iii) Arrangement to shield fuel impinging tube surface: The arrangement of shielding of service exposed economiser tubes particularly towards the coal-ash impinging side with SA213 304H stainless tube halves of $2.5 \mathrm{~mm}$ thick and internal diameter of 38.1 $\mathrm{mm}$ (1.5 inch) may reduce the impingement linked erosion effect.

In oil and coal-fired boilers, soot build-up on tubes acts as an insulator against heat transfer. Any such deposits should be removed on a regular basis. An estimated 1\% efficiency loss occurs with every $22^{\circ} \mathrm{C}$ increase in stack temperature. Therefore, stack temperature should be checked and recorded regularly as an indicator of soot deposits. It is also estimated that $3 \mathrm{~mm}$ of soot can cause an increase in fuel consumption by $2.5 \%$ due to increased flue gas temperatures. Periodic off-line cleaning of tube surfaces within furnace, boiler tube banks, economisers and air heaters may be necessary to remove stubborn deposits. Reduction of boiler steam pressure is an effective means of reducing fuel consumption by as much as 1 to $2 \%$. Lower steam pressure gives a lower saturated steam temperature and without stack heat recovery, a similar reduction in the temperature of the flue gas is obtained. Since the unit has not undergone a performance guarantee test to assess the performance, a boiler tuning test may be done to check the effectiveness of all set points of control parameters for available fired fuel and its composition.

\section{References}

1. Mohammad A. Malek, Ph.D., P.E.(2007): Heating Boiler Operator's Manual: Maintenance, Operation, and Repair. Appendix B: Maximum Allowable Stress Values for Ferrous Materials, Chapter (McGraw-Hill Professional).

2. O\&M Manual of 135 TPH Single Drum Coal Fired Circulating Fluidised Combustion Water Tube Boiler with Cold Cyclone Technology (Make Thyssenkrupp Industries India Ltd.)

3. Tube sample test report of $\mathrm{M} / \mathrm{s}$ Indicative Consultant India dated 03.11.16

4. Boiler Slag/scale sample test report of $\mathrm{M} / \mathrm{s}$ Indicative Consultant India dated 31.10.16

5. Fired fuel mix sample test report of $\mathrm{M} / \mathrm{s}$ Indicative Consultant India dated 22.9.16

6. Bhattacharya, C. (2000): "Minimizing Erosion - Factor Which Costs the active Life of Atmospheric Fluidised Bed Boilers" Proceedings of National Conference on material issues of Fluidized Bed Boilers; pp.33-44, 2- 
3.12.2000; NPTI-ER/Durgapur, Dalhousie University \& Greenfield Research Inc. Canada; Durgapur, W. Bengal.

7. Bhattacharya, C.; Sarkar, H. S.(2003): "Economic Assessment of Utilization of Beneficiated Indian Power Coal for Thermal Power Generation" (April 2003); National Symposium (SRP-2003) CMERI (CSIR)/Durgapur/INDIA .(Abstracted PP: 46-47).

8. Bhattacharya, C.; Saha, B.; Manna, J.; Bera, S. (2007): "Impact of Boiler Tube failure in Power Pricing \&
Profitability" Proceedings of National Conference on Enhancement of Plant Availability by Life Assessment \& Condition Monitoring (LACOM2007), 19-20.12.2007; CMERI (CSIR), Durgapur.

9. Course material for Onsite Workshop on "Boiler Tube Failure \& its Remedy" 18-19.12.2006; for DVC; CTPS, Chandrapura -Edited by Chittatosh Bhattacharya.

10. Indian Boiler Regulation 1960 (As amended 2004) Published Version 2007.

11. ASME PTC 4.0 2008 Fired Steam Generators

\section{Indian Journal of POWER \& RIVER VALLEY DEVELOPMENT OTPC - A SUCCCCESS STORY CONTENTS}

1. O\&M BEST PRACTICES AT ONGC TRIPURA POWER COMPANY LTD

2. WORLD CLASS MAINTENANCE PRACTICES IN CONTROL \& INSTRUMENTATION AT OTPC

3. FORCED COOLING OF GE9FA GAS TURBINE FOR EMERGENCY MAINTENANCE AT OTPC

4. OTPC GE9FA GAS TURBINE \#2 DIFFUSER DUCT CRACK RECTIFICATION

5. MANAGING MAJOR SHUTDOWN AND MAINTENANCE OF LARGE SIZED GAS-FIRED COMBINED CYCLE POWER PLANT: A JOURNEY TOWARDS EXCELLENCE

6. OTPC - A SUCCESS STORY

\begin{abstract}
Satyajit Ganguly, Managing Director, Sudin Chattopadhyay, Bibek Roy, Narendra Gupta, Bhaskar, Senchowdhury, Smruti Ranjan Das and Md. Musa, Executive Engineers, ONGC Tripura Power Co. Ltd, New Delhi
\end{abstract}

Meen Sharma, Pradip Debnath and Mohammad Musa, Executive Engineers, ONGC Tripura Power Co Ltd, New Delhi

Narendra Kumar Gupta, Soubhik Choudhury, Soham Dey and Bibek Roy, Executive Engineers, ONGC Tripura Power Co Ltd, New Delhi

Bibek Roy, Tapas Bhowmik, Bhaskar Senchowdhury and Biswajit Sarkar, Executive Engineers, OGGC Tirpura Power Co Ltd, New Delhi

Bibek Roy, Executive Engineer, Satyajit Ganguly, Managing Director and Sudin Chapadhyay, Executive Engineer, ONGC Tripura Power Co Ltd, New Delhi

For copies, please contact :

The Manager

BOOKS \& JOURNALS PVT. LTD.

62Lenin Sarani, Kolkata 700 013 •E-mail:bnjournals@gmail.com 